\title{
Melodic pattern test of temporal processing: an analysis of different types of responses
}

\author{
Teste melódico de processamento temporal: análise de diferentes
}

formas de respostas

\author{
Tainá Betti', Rubia Soares Bruno', Sheila Jacques Oppitz², Mirtes Bruckmann"2, Michele Vargas Garcia'
}

\begin{abstract}
Purpose: Evaluate the results of the different forms of responses in the melodic temporal ordering test in relation to frequency and duration. Methods: The sample was composed of 33 subjects, for convenience, aged between 17 and 27 years old, normal hearing individuals, presenting no complaints regarding auditory processing and having no hearing impairment, syndromes or craniofacial malformation history; no physical disability (manual), as well as no neurological and speech impairment and education level greater than nine years. They were subjected to the temporal ordering test with musical tone, called melodic Duration Pattern Test (DPT) and Frequency Pattern Test (FPT), applied under three response conditions (motor, humming and motor), performed on the same date. For that, at a first moment, the induvial were asked to recognize the stimuli verbally, then characterize the stimuli in an imitative pattern and, finally, to recognize the stimuli in manual responses. Results: Statistically significant differences were not observed between the three forms of responses for DPT and FPT. However, it is remarkable that there was a greater number of changes for FPT than for DPT, regardless the form of response. Furthermore, motor and verbal responses presented more changes for humming, in FPT. Conclusion: The different forms of response (motor, humming and motor) for the melodic DPT and FPT did not change the results.
\end{abstract}

Keywords: Hearing; Hearing tests; Auditory perception; Social discrimination; Auditory cortex

\begin{abstract}
RESUMO
Objetivo: Avaliar os resultados nas diferentes formas de respostas no teste melódico de ordenação temporal para frequência e duração. Métodos: A amostra foi composta por 33 sujeitos, por conveniência, com idade entre 17 e 27 anos, normo-ouvintes, sem queixas de processamento auditivo e de histórico de risco para alterações auditivas, ausência de síndromes ou malformações craniofaciais, deficiência física (manual), bem como de alterações neurológicas e de linguagem e com escolaridade superior a nove anos de estudo. Os sujeitos foram submetidos ao teste de ordenação temporal com tom musical, a saber: Teste de Padrão de Duração (TPD) e Teste de Padrão de Frequência (TPF), aplicados sob três condições de respostas (verbal, humming e motor,) e realizados na mesma data. Para isso, os sujeitos foram solicitados, primeiramente, a reconhecer os estímulos verbalmente, em seguida a caracterizar os estímulos em um padrão imitativo e, por fim, a identificar os estímulos com respostas manuais. Resultados: Não houve diferenças significativas entre as três formas de resposta para o TPD e TPF. No entanto, observou-se que, para o TPF, houve maior número de alterações que o TPD, independente da forma de resposta. Ainda, as formas motor e verbal tiveram mais alterações que o humming, no TPF. Conclusão: As diferentes formas de respostas (verbal, humming e motor) para os testes TPD e TPF melódicos não alteram o seu resultado.
\end{abstract}

Descritores: Audição; Testes auditivos; Percepção auditiva; Discriminação social; Córtex auditivo

\footnotetext{
This work was carried out at the Speech, Hearing and Language Sciences Course, Universidade Federal de Santa Maria - UFSM - Santa Maria (RS), Brazil. (1) Speech, Hearing and Language Sciences Course, Universidade Federal de Santa Maria - UFSM - Santa Maria (RS), Brazil.

(2) Graduate Program (Master's Degree) in Human Communication Disorders, Universidade Federal de Santa Maria - UFSM - Santa Maria (RS), Brazil. Funding: Scholarship from the Research Incentive Fund (FIPE).

Conflict of interests: No

Authors' contribution: $T B$ and $S J O$ participated in the interpretation of results, research on the literature and theoretical aspects; $R S B$ participated in the collection, analysis and interpretation of data; $M B$ contributed to the critical review of the content; $M V G$ was responsible for the project and overall direction of the stages of implementation and preparation of the manuscript.
}

Corresponding author: Tainá Betti. E-mail: taainabetti@ hotmail.com

Received on: 3/2/2016; Accepted on: 5/30/2016 


\section{INTRODUCTION}

Auditory Processing (AP) corresponds to a number of mechanisms and processes perceived by the human ear that, when separated by an interval greater than two milliseconds, enables the acoustic and metacognitive analysis of sounds ${ }^{(1)}$.

Such processing is responsible for behavioral phenomena, such as localization and lateralization of sound, auditory discrimination, auditory pattern recognition, temporal features of hearing, including: resolution, masking, integration and temporal ordering, auditory performance with competitive acoustic signals and auditory performance with degraded acoustic signals $^{(1)}$.

According to the literature, the Frequency Pattern Test (FTP) and the Duration Pattern Test (DPT) are the two main tests that evaluate the temporal ordering skill. Tonal patterns are recognized as music or melody because they are composed of tones of different frequencies and durations in different temporal orders ${ }^{(2)}$. Temporal auditory processing is an essential skill, since it is the primary source of information of all the auditory signals ${ }^{(3,4)}$.

Auditory perception of temporal ordering is the discrimination capacity of the complex and fast sound components, due to the order of occurrence, within a defined time interval ${ }^{(5,6,7,8,9,10)}$. This skill is important in the process of encoding the temporal information of the sound, such as its duration, interval and order of appearance of the stimuli(11,12), because in continuous speech, speech segments are co-articulated, in other words, its acoustic pattern is changed in relation to the duration, intensity and frequency ${ }^{(13)}$.

Thus, it is the responsibility of the listener to analyze the acoustic cues that the speaker emits, organizing the speech segments of the acoustic point of view, in a sequential order which is defined by the language patterns that he learned ${ }^{(13)}$.

Sequencing is one of the most basic and important functions of the central auditory system and the recognition, as well as the identification of auditory patterns, involve a diversity of perceptual and cognitive processes ${ }^{(4,14)}$. The recognition of these patterns requires the individual to understand the difference between verbal and non-verbal acoustic elements and, as a consequence, to perform the temporal ordering of such elements, which enables the extraction and the use of the prosodic features of speech such as rhythm, tone, accent, intonation and a sequence of vowels and consonants, according to the pattern of the learned language $e^{(4)}$.

Among the identification tests for temporal ordering skill that are proposed in the literature, there are tests such as FTP and DPT, constructed by Taborga-Lizarro ${ }^{(15)}$, which are made up of stimuli of musical sounds of flute. FTP is composed of musical sounds in the frequency of $440 \mathrm{~Hz}$ for bass sound, and $493 \mathrm{~Hz}$ for treble sound, with a fixed duration, applied to $50 \mathrm{~dB}$ NS. The melodic DPT stimuli are made of long musical tones $(2000 \mathrm{~ms})$ and short ones $(500 \mathrm{~ms})$, applied in ten sequences of three stimuli and ten sequences of four stimuli, with a fixed frequency of $440 \mathrm{~Hz}$ and interstimulus interval of 6 milliseconds. The normal range for FTP of three sounds is over than $70 \%$ of correct answers and, for FPT, the percentage increased to $100 \%$. In the evaluation of four sounds, the degree of normality for FTP is $60 \%$ of correct answers and, for DPT, percentage increased to $90 \%{ }^{(16)}$.

There are also different response modalities for temporal ordering tests. Stimuli can be answered verbally by humming (imitation), or even manually pointing to a drawing that represents them ${ }^{(16)}$.

The use of humming allows the examinee to receive and express the response at first in the right hemisphere (non-linguistic dominant), while verbal response requires the use of both hemispheres to recognize the stimulation, in which the right hemisphere should recognize the acoustic contour of the pattern and the left hemisphere must convert the pattern in a verbal response. Both hemispheres should interact appropriately to a correct verbal response to the auditory pattern ${ }^{(17)}$.

According to a study, verbal responses seem to be more difficult, especially in individuals with language problems, when compared to other forms of response, because they involve more complex cognitive processes of attention, description of the actual order of the components, a definition of a concept that could represent each perceived stimulus and accurate articulation movements of speech while pronouncing the selected word ${ }^{(17)}$.

Then, the aim of this study was to evaluate the results in different forms of responses in melodic temporal ordering test for frequency and duration in adults with normal hearing. The relevance of this study is related to the importance of understanding whether different forms of response influence the result of the temporal ordering tests, as the literature of the area suggests several possibilities of response (verbal, humming and motor).

It is believed that differences in the results among the three forms of response should not happen, since the sample of this study is composed of normal individuals, in other words, individuals without hearing, neurological and language disorders, as well as individuals without craniofacial deformities and physical disability. These factors may contribute to the occurrence of changes in the test, with regard to the understanding and execution.

\section{METHODS}

This research was approved by the Research Ethics Committee (REC) of Universidade Federal de Santa Maria, under the protocol number 25933514.1.0000.5346.

Only individuals who agreed to participate voluntarily and individuals who signed the Consent Form (CF), in which the procedures to be performed were described, participated in the sample selection process.

This study is a descriptive research, with quantitative and 
cross-sectional approach, with convenience sample. The sample consisted of young adults, who followed some inclusion criteria, such as: normal hearing, without auditory processing complaints and without history of risk for hearing, neurological and language changes, absence of middle ear disorders, present contralateral acoustic reflexes and education level superior to nine years of schooling. Then, for exclusion criteria, the individuals could not present: speech therapy history, syndromes or craniofacial malformations, physical disability (manual), neurological impairment or suggestive signs of it, history of language disorders (factors that could contribute to the appearance of changes in the test, with regard to their understanding and execution), school failure or suggestive signs for learning difficulties, difficulty in understanding speech in quiet and in noise, knowledge or notions of musical instrument and a foreign language.

In order to verify the appropriateness of volunteers to the study criteria, the following procedures were performed: anamnesis, Visual Inspection of the External Auditory Canal (EAC), Pure Tone Audiometry (PTA), Speech Recognition Threshold (SRT), Speech Recognition Percentage Index (SRPI) and Acoustic Immittance Measures (AIM).

The anamnesis was carried out from the medical history of the individuals, who were asked about some points that could influence the AP, such as the presence of other family members with complaints, emotional and social development data, memory difficulties, attention and sound localization, learning difficulties and speech recognition in quiet and in noise.

For visual inspection of AIM and reject any changes that could influence the audiometric thresholds, the Klinic WelchAllyn ${ }^{\circledR}$ clinical otoscope was used.

PTA was performed in an acoustically treated booth, with the help of TDH39 supra-aural headphones and Fonix Hearing Evaluator ${ }^{\circledR}$ audiometer, FA 12 model type I. The hearing thresholds were investigated in the frequencies from 250 to $8000 \mathrm{~Hz}$, in a monaural form. It was used the descending-ascending technique and established normality criteria was hearing thresholds up to $25 \mathrm{~dB} \mathrm{HL}$, in all tested frequencies ${ }^{(18)}$.

Acoustic Immittance Measures were performed through the AT235 middle ear analyzer unit, Interacoustics ${ }^{\circledR}$, for searching the tympanometric curve and contralateral acoustic reflex (500 to $4000 \mathrm{~Hz}$ ), bilaterally ${ }^{(19)}$.

Thus, the sample consisted of 33 individuals, 29 women and four men, aged between 17 and 27 years old, all with mean hearing thresholds of $6.14 \mathrm{~dB}$ HL in the right ear and $5.55 \mathrm{~dB}$ $\mathrm{HL}$ in the left ear and type A bilateral tympanogram.

The evaluation of the hearing skill of temporal ordering has always been performed by the same speech therapist, in order to avoid deviations and differences in collection procedures. The individuals were submitted to the versions of FTP and DPT, temporal ordering tests of Taborga-Lizarro ${ }^{(15)}$. Responses were asked in the following order: oral, humming and then motor. The tests were applied on the same date, first
DPT, followed by FPT, with an interval of 5 minutes of rest after each. It was asked to the individuals that, initially, they recognize the stimuli verbally, then that they characterize the stimuli in an imitative pattern and, finally, to recognize the stimuli with manual responses (showing hands - small and large, with the fingers - thin and thick). The non-randomization of the answers was chosen because it is believed that this could generate some learning to the participants, as they had been submitted three times to each test, in order to obtain the three different forms of responses.

The tests were performed in an acoustically treated booth, with supra-aural earphone to $40 \mathrm{dBHL}$, binaural mode. It was used the clinical audiometer of two channels, Fonix Hearing Evaluator®, model FA 12 Type I and earphones TDH-39P, Telephonics ${ }^{\circledR}$, coupled to a computer through an interface cable, from the headphone jack to one of the $\mathrm{CD} /$ tape inputs of the audiometer. For data analysis, it was calculated the number of correct answers and the percentage was established. Inversions were considered as errors.

For the statistical analysis, it was used the Test of Equality of Two Proportions. In all analyses, a significance level of 5\% $(\mathrm{p} \leq 0,05)$ was considered.

\section{RESULTS}

In relation to DPT, all individuals presented $100 \%$ of normality in the 3 forms of response, for 3 and 4 sounds. On the other hand, for FTP, only individuals who showed $100 \%$ of correct answers with 3 sounds were the ones who performed the test with 4 sounds. The distribution of the relative frequency and percentage of individuals with normal and changed results in the forms to answer FTP is shown in Table 1.

For DPT, the percentages of correct answers continued the same, regardless of the form of response. For FTP, it was observed greater number of errors in relation to DPT, and, in relation to the form of response, the humming, for example, presented fewer errors. When the individuals presented change in one form of response, they maintained this change in the other two forms.

It was observed that there was no significant difference between the three forms to answer, both for the distribution of the changed ones, as for the normal ones, in the 2 tests. P-values of the comparisons, in pairs, between the forms for each test are shown in Table 2.

\section{DISCUSSION}

According to the results that were collected, no significant differences were observed between the three forms of response for DPT and FTP, as shown in Table 2.

One study ${ }^{(17)}$ that was carried out with ten individuals with Parkinson's, aged from 50 to 70, verified no difference in the form of response. DPT and FTP were performed in a free field, 
Table 1. Descriptive analysis of the percentages of normal and changed individuals for Frequency Pattern test, for the different forms of response

\begin{tabular}{|c|c|c|c|c|c|c|c|c|}
\hline & \multicolumn{8}{|c|}{ Frequency Pattern Test } \\
\hline & \multicolumn{4}{|c|}{ With 3 sounds } & \multicolumn{4}{|c|}{ With 4 sounds } \\
\hline & $\mathrm{N}$ & $\%$ & C & $\%$ & $\mathrm{~N}$ & $\%$ & C & $\%$ \\
\hline Humming & 25 & 75.80 & 8 & 24.20 & 25 & 100 & 0 & 0 \\
\hline Motor & 22 & 66.70 & 11 & 33.30 & 22 & 100 & 0 & 0 \\
\hline Verbal & 22 & 66.70 & 11 & 33.30 & 22 & 100 & 0 & 0 \\
\hline
\end{tabular}

Subtitle: $\mathrm{N}=$ normal individuals; $\mathrm{C}=$ changed individuals

Test of Equality of Two Proportions $(p<0.05)$

Table 2. Statistical analysis of the comparison between the forms of response (verbal, motor and humming) in both tests

\begin{tabular}{|c|c|c|c|}
\hline & & Humming & Motor \\
\hline \multirow{2}{*}{3 Sounds Melodic Duration } & Motor & 1.000 & \\
\hline & Naming & 1.000 & 1.000 \\
\hline \multirow{2}{*}{4 Sounds Melodic Duration } & Motor & 1.000 & \\
\hline & Verbal & 1.000 & 1.000 \\
\hline \multirow{2}{*}{3 Sounds Melodic Frequency } & Motor & 0.415 & \\
\hline & Verbal & 0.415 & 1.000 \\
\hline \multirow{2}{*}{4 Sounds Melodic Frequency } & Motor & 1.000 & \\
\hline & Verbal & 1.000 & 1.000 \\
\hline
\end{tabular}

Test of Equality of Two Proportions ( $p<0.05)$

to $80 \mathrm{~dB}$, with participants who presented hearing thresholds, or hearing loss that does not exceed $60 \mathrm{~dB}$. This study differs from the above, since it did not find any difference between the forms to answer. It is believed that there was no difference for such study due to the pathology presented in the group and the age of the individuals, which did not occur with the individuals of this study, who were young adults and did not have any associated pathology.

In another study ${ }^{(9)}$, it was verified the performance of 12 children with phonological disorders, in ordering and temporal resolution tests. In order to evaluate the temporal ordering, FTP was used and each participant was asked to repeat the items in the forms of imitation - through murmur - and naming. Considering the 12 children who were evaluated, it was found appropriate response (verbal) in $75 \%$ of them and changed in $25 \%$, being necessary to test them in the humming version. In this study, there was no significant difference in the comparison between the different forms to answer, however, more affected individuals were noticed in the motor and verbal forms to answer, which confirms the findings.

Also in relation to the forms to answer, there is a study ${ }^{(20)}$ which was performed on children without language impairments. It found that for FTP there was a significantly better difference for the non-verbal response in relation to verbal responses. It is believed that the incident may be attributed to the need for inter-hemispheric integration of the stimuli in the request of verbal response, which does not occur in non-verbal request. The present study is in agreement with this, since it was possible to identify the lowest number of errors for the non-verbal response, although no significant difference between the methods was observed.

On the other hand, other authors ${ }^{(21,22)}$ compared different forms to answer (verbal, motor and humming) while analyzing the performance of children with disorder of normal learning. They found that the children were able to perform humming, but they presented great difficulty while answering orally or manually, unlike the children who were considered normal, which showed little or no difference in response. Thus, it can be said that this study is in agreement with the mentioned study in relation to normal children. In contrast, for children with learning difficulties, this finding shows that the form of response should be strongly considered, depending on the presented pathology.

In relation to the performance in both tests, a study ${ }^{(23)}$ with users of cochlear implant (CI) tried to evaluate the auditory skill of temporal ordering, through DPT and FTP, and it verified that to verbally answer, individuals performed better on DPT. This study is consistent with the results obtained in our study, in which it was also observed that individuals performed better in DPT.

The same result was found in a study with students, in which individuals showed better performance in DPT when compared to FTP ${ }^{(24)}$. The results of this study confirm these findings, since it evidenced better performance for DPT, being possible to infer that this is possibly due to the difference between the stimuli, which is greater in DPT than TPF.

Authors ${ }^{(16)}$ also believe that brain processes such as perception of duration are different from the processes of frequency of 
perception and that tests can detect different brain dysfunctions between them.

Other studies that were carried out with different versions of DPT and FTP, in diverse populations, also found a higher percentage of correct answers for DPT than for $\mathrm{FTP}^{(2,25,26)}$.

In the literature, it was found three studies comparing the three forms of responses in normal individuals ${ }^{(27,28,29)}$ and, in none of them, significant differences were observed when comparing the forms of responses. In this study, such findings were also verified, agreeing with those authors. However, most participants mentioned the verbal form as the easiest, which diverges from the results, since the individuals presented higher frequency of correct answers regarding humming.

It is evident in this study that for normal individuals, there is no difference in the test results, for the three forms of responses, which indicates that the reviewer can use any of them. However, it is suggested to analyze with attention the choice in relation to the mode of response in individuals with diseases or other changes, taking into account other studies with these populations, because depending on the given condition, some differences may exist, as explained in previous studies. It was also verified the need to carry out FTP along with DPT, since individuals without complaints showed $100 \%$ of normality for DPT and showed changes for FTP.

Depending on the characteristics of the individuals who participated in the current research, as full maturation age of the central nervous system (CNS), high level of education and lack of neurological disorders, most of them showed no difficulty in carrying out the tests, however, since CNS integrity is compromised, either by the presence of auditory processing disorders, and by age, the individuals might present some difficulties in the tests and the form of response may have some influence on the results ${ }^{(30)}$. However, for normal individuals, difference in the responses should not occur, in other words, the result should remain normal or changed, independently of the response method.

A study with a larger sample, with the same characteristics of this study, could confirm this hypothesis.

\section{CONCLUSION}

The different forms of response (motor, humming and verbal) for DPT and FTP melodic tests did not change the result in normal hearing adults.

\section{REFERENCES}

1. American Speech-Language Hearing Association - ASHA. (Central) Auditory processing disorders: technical report. Rockville: American Speech-Language Hearing Association; 2005 [acesso 16 nov 2015]. Disponível em: http://www.asha.org/policy/TR2005-00043/

2. Onoda RM, Pereira LD, Guilherme A. Reconhecimento de padrão temporal e escuta dicótica em descendentes de japoneses, falantes e não-falantes da língua japonesa. Rev Bras Otorrinolaringol. 2006;72(6):737-46. http://dx.doi.org/10.1590/ S0034-72992006000600004

3. Shinn JB. Temporal processing: the basics. Hear J. 2003;56(7):52. http://dx.doi.org/10.1097/01.HJ.0000292557.52409.67

4. Terto SSM, Lemos SMA. Aspectos temporais auditivos: produção de conhecimento em quatro periódicos nacionais. Rev CEFAC. 2011;13(5);926-36. http://dx.doi.org/10.1590/S151618462011005000050

5. Zaidan E, Garcia AP, Tedesco MLF, Baran JA. Desempenho de adultos jovens normais em dois testes de resolução temporal. Pro Fono. 2008;20(1):19-24. http://dx.doi.org/10.1590/S010456872008000100004

6. Muniz LF, Roazzi A, Schochat E, Teixeira CF, Lucena JA. Avaliação da habilidade de resolução temporal, com uso do tom puro, em crianças com e sem desvio fonológico. Rev CEFAC. 2007;9(4):55062. http://dx.doi.org/10.1590/S1516-18462007000400016

7. Balen SA, Massignani R, Schillo R. Aplicabilidade do software fast forword na reabilitação dos distúrbios do processamento auditivo: resultados iniciais. Rev CEFAC. 2008;10(4):572-87. http://dx.doi. org/10.1590/S1516-18462008000400018

8. Samelli AG, Schochat E. Processamento auditivo, resolução temporal e teste de detecção de gap: revisão de literatura. Rev CEFAC. 2008;10(3):369-77. http://dx.doi.org/10.1590/S151618462008000300012

9. Santos JLF, Parreira LMMV, Leite DRC. Habilidades de ordenação e resolução temporal em crianças com desvio fonológico. Rev CEFAC. 2010;12(3):371-6. http://dx.doi.org/10.1590/S151618462010005000026

10. Nishihata M, Vieira MR, Pereira LD, Chiari BM. Processamento temporal, localização e fechamento auditivo em portadores de perda auditiva unilateral. Rev Soc Bras Fonoaudiol. 2012;17(3):266-73. http://dx.doi.org/10.1590/S1516-80342012000300006

11. Jacob LCB, Alvarenga KF, Zeigelboim B. Avaliação audiológica do sistema nervoso auditivo central. Arq Int Otorrinolaringol. 2000;4(4):144-51.

12. Phillips SL, Gordon-Salant S, Fitzgibbons PJ, Yeni-Komshian G. Frequency and temporal resolution in elderly listeners with god and poor word recognition. J Speech Lang Hear Res. 2000;43(1):217-28. http://dx.doi.org/10.1044/jslhr.4301.217

13. Watson BU, Miller T. Auditory perception, phonological processing and reading ability/disability. J Speech Lang Hear Res. 1993;36(4):850-63. http://dx.doi.org/10.1044/jshr.3604.850

14. Tallal P, Newcombe F. Impairment of auditory perception and language comprehension in dysphasia. Brain Lang. 1978;5(1):13-34. http://dx.doi.org/10.1016/0093-934X(78)90003-2

15. Taborga MBL. Processos temporais auditivos em músicos de Petrópolis. [monografia]. Rio de Janeiro: Universidade Federal de São Paulo; 1999.

16. Pereira LD, Schochat E. Testes auditivos comportamentais para avaliação do processamento auditivo central. São Paulo: Pró-Fono; 2011.

17. Miranda ES, Pereira LD, Bommarito S, Silva TM. Avaliação do 
processamento auditivo de sons não-verbais em indivíduos com doença de Parkinson. Rev Bras Otorrinolaringol. 2004;70(4):534-9. http://dx.doi.org/10.1590/S0034-72992004000400015

18. Lloyd LL, Kaplan H. Audiometric interpretation: a manual of basic audiometry. Baltimore: University Park Press; 1978.

19. Hall JW, Chandler D. Timpanometria na audiologia clínica. In: Katz J. Tratado de audiologia clínica. 4a ed. São Paulo: Manole; 1999. p. 281-97.

20. Balen SA. Reconhecimento de padrões auditivos de frequência e de duração: desempenho de crianças escolares de 7 a 11 anos [dissertação]. São Paulo: Universidade de São Paulo; 2001.

21. Musiek FE, Geurkink NA. Auditory perceptual problems in children: considerations for the otolaryngologist and audiologist. Laryngoscope. 1980;90(6 Pt 1):962-71.

22. Musiek FE, Geurkink NA, Kietel S. Test baterry assessment of auditory perceptual in children. Laryngoscope. 1982;92(3):251-7. http://dx.doi.org/10.1288/00005537-198203000-00006

23. Campos PD, Alvarenga KF, Frederique NB, Nascimento LT, Sameshima K, Costa Filho OA et al. Habilidades de ordenação temporal em usuários de implante coclear multicanal. Rev Bras Otorrinolaringol. 2008;74(6):884-9. http://dx.doi.org/10.1590/S003472992008000600011

24. Nascimento LS, Lemos SMA. A influência do ruído ambiental no desempenho de escolares nos testes de padrão tonal de frequência e padrão tonal de duração. Rev CEFAC. 2012;14(3):390-402. http:// dx.doi.org/10.1590/S1516-18462011005000093
25. Parra VM, Iório MCM, Mizahi MM, Baraldi GS. Testes de padrão de frequência e de duração em idosos com sensibilidade auditiva normal. Rev Bras Otorrinolaringol. 2004;70(4):517-23. http://dx.doi. org/10.1590/S0034-72992004000400013

26. Terto SSM, Lemos SM. A. Aspectos temporais auditivos em adolescentes do $6^{\circ}$ ano do ensino fundamental. Rev CEFAC. 2013;15(2):271-86. http://dx.doi.org/10.1590/S151618462012005000040

27. Pinheiro ML, Tinta T. Diferences among response mode in pitch pattern perception. In: Andrews JR, Burns MS, editors. Selected papers in language and phonology. Evanston: Institute for Continuing Profissional Education; 1977. Vol. 2.

28. Musiek FE. Aplicação de testes auditivos centrais: uma abordagem geral. In: Katz J. Tratado de audiologia clínica. São Paulo: Manole; 1989. p. 323-39.

29. Corazza MC. Avaliação do processamento auditivo central em adultos: teste de padrões tonais auditivos de frequência e teste de padrões tonais auditivos de duração [tese]. São Paulo: Universidade Federal de São Paulo; 1998.

30. Delecrode CR, Cardoso ACV, Frizzo ACF, Guida HL. Testes tonais de padrão de frequência e duração no brasil: revisão de literatura. Rev CEFAC. 2014;16(1):283-93. http://dx.doi.org/10.1590/1982021620143912 